\section{On the Mechanism of the Cation- and Substrate Analog-activated Enzyme Reaction: Glucosamine-6-phosphate Deaminase}

We present the case of glucosamine-6-phosphate deaminase reaction in which the production of fructose-6phosphate $(p)$ occurs in the absence and presence of di-
It appears that the essential feature of the mechanism suggested here is the enhancement of the rate by the chelation between ES complex and the latter's in the presence of the cations and substrate analogue. It is possible that both the substrate and analogue are bound to the enzyme surface to provide rigidity for favourable chelation. The mechanism proposed can be of value in understanding the activation of enzyme reactions 5 .
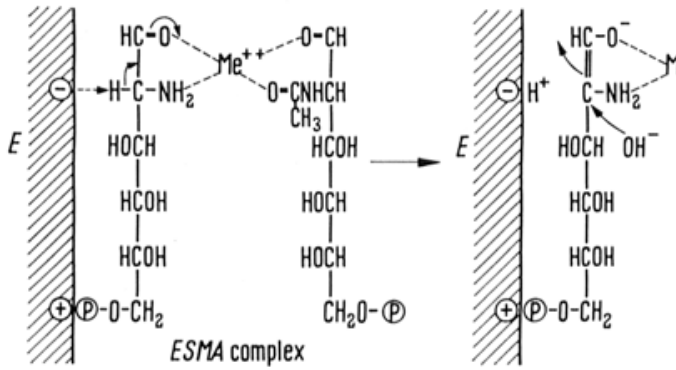

valent cations such as $\mathrm{Mn}^{++}, \mathrm{Hg}^{++}$and $\mathrm{Co}^{++}$and the substrate analogue $(A), \mathrm{N}$-acetyl glucosamine-6-phosphate, respectively, but with the maximum rate in the presence of both the cation and the analogue ${ }^{1}$. The rate of the reaction can be expressed as follows:

$$
d p / d t=k(E S)+k^{\prime}(E S M)+k^{\prime \prime}(E S M A)
$$

where $k$ 's are rate constants, and (ES), (ESM) and $(E S M A)$ are the enzyme-substrate, enzyme-substratemetal and enzyme-substrate-metal-analogue complexes, respectively.

From the $\mathrm{pH}$ profile of the reaction with the maxima at $\mathrm{pH} 8^{1}$ and $8.5^{\mathbf{2}, 3}$, a possible mechanism of the reaction can be suggested, accounting for the overall reaction in the presence of both the cations and substrate analogue.

The first step may be the formation of a chelate between ES complex and the analogue. Then, a basic group with high $\mathrm{pK}$ predictable from the $\mathrm{pH}$ profile may deprotonate carbon 2 of the substrate bound, followed by the shift of the pair of electrons towards the carbonylmetal bond. The resulting enolate ${ }^{4}$ will subsequently be hydrated and deamination assisted by the chelation will follow, as shown below:

where $E$ represents the enzyme molecule.

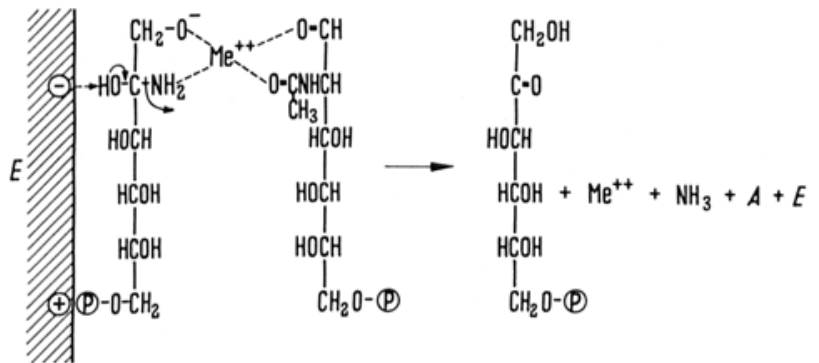

Zusammenfassung. Die Reaktion der Glukosamin-6Phosphat-Deaminase, an der Metallionen und ein Substratanalogon teilnehmen, wurde vom mechanistischen Standpunkt aus bearbeitet und auf der Basis der Komplexierung des $E S$-Komplexes mit den obengenannten Aktivatoren dargestellt.

\section{P.-S. SONG ${ }^{6}$}

Biophysics Laboratory, Atomic Energy Research Institute, Seoul (Korea), October 27, 1963.

1 T. N. S. Varma and B. K. Bachiawat, Biochim. biophys. Acta $69,464(1963)$.

2 D. G. ComB and S. Roseman, J. biol. Chem. 232, 807 (1958).

8 T. N. Pattabiraman and B. K. Bachhawat, Biochim. biophys. Acta 54, 273 (1961).

4 The fact that a significant amount of enol was formed in the alkaline solution of 2-amino-D-glucose supports existence of such an enolate intermediate in the enzyme reaction (P.-S. Song and C. O. Chichester, unpublished work).

5 Acknoteledgment. The author expresses his appreciation to the Office of Atomic Energy, Korea, for financial support.

- Present address: University of California, Davis (California, U.S.A.).

\section{Red Cell Agglutination by S Protein, a Lipoprotein from Erythrocyte Stroma}

It was previously reported by DE C. BAKER ${ }^{1}$ that homologous and some heterologous red cells were agglutinated by haemolysates made from rabbit, rat and guinea-pig red cells. Evidence was also available that this phenomenon was probably due to a substance liberated from the stroma, rather than to haemoglobin, since the filtered haemoglobin produced no agglutination of intact red cells.

The following study was undertaken to investigate this possibility. Therefore, the protein now known as $\mathrm{S}$ pro- tein, was separated from the cells of man and of a number of different animals by the original method of Moskowirz et al. ${ }^{2}$. Isotonicity was then restored by dialysis against large quantities of buffered $\mathrm{NaCl}$ in the cold for $48 \mathrm{~h}$. Final centrifugation was always necessary for elimination of some residual turbidity. The $\mathrm{NaCl}$-buffer recommended by PONDER ${ }^{3}$ for the red cells, is made by mixing $75 \mathrm{ml}$ of

1 S. B. DE C. BAKER, Nature 185, $547(1960)$.

2 M. Moskowitz, W. B. Dandliker, M. Calvin, and R. S. Evans, J. Immunol. 65,383 (1950).

- E. Pondre, Hemolysis and Related Phenomena (Grune \& Stratton, New York 1948), p. 104. 